\title{
PENGARUH PROGRAM PNM MEKAAR TERHADAP PENDAPATAN MASYARAKAT MISKIN KECAMATAN CAMPALAGIAN
}

\author{
Rahmadina, Rahmah Muin \\ Hukum Ekonomi Syariah, Fakultas Agama Islam, Universitas Al Asyariah Mandar \\ rahmadina.alimin@gmail.com, rahmahheksyar@gmail.com
}

\begin{abstract}
Abstrak
Penelitian ini bertujuan untuk: 1). Mengetahui mekanisme kerja PNM MEKAAR dalam menjalankan program bantuan permodalan, 2). Mengetahui pengaruh program PNM MEKAAR terhadap pendapatan masyarakat miskin Kecamatan Campalagian. Metode pengumpulan data yang dilakukan yaitu dengan angket, observasi, wawancara dan dokumentasi, serta mengumpulkan data dari angka-angka dan menafsirkannya kedalam bentuk tabulasi. Mekanisme kerja PNM MEKAAR Dalam Memberikan Bantuan Permodalan benar-benar ditujukan untuk masyarakat yang kurang mampu dengan mensurvei setiap keluarga yang akan diberikan bantuan modal, untuk dididik dalam memberikan pelatihan melalui pengelolaan usaha sehingga dapat membantu nasabah dalam meningkatkan pendapatan dan diberikan modal agar mereka dapat tumbuh menciptakan usaha secara mandiri. Pengaruh PNM MEKAAR Terhadap Pendapatan Masyarakat Miskin Kecamatan Campalagian sangat berpengaruh. Dengan adanya program PNM MEKAAR Cabang Campalagian dengan bantuan permodalan tersebut masyarakat yang bergabung dalam suatu kelompok yang telah mengelola usahanya dengan baik telah dapat menghasilkan keuntungan yang sudah dapat memenuhi kebutuhan individu maupun kebutuhan keluarga.
\end{abstract}

Kata Kunci : PNM MEKAAR, Pendapatan Masyarakat Miskin

\begin{abstract}
This research aims to: 1). Know the work mechanism PNM MEKAAR in carrying out capital assistance programs, 2). Know the effect of the program PNM MEKAAR to the income of the poor Campalagian district. Data collection metods carried out that is with kuesioner, observation, interview, and documentation, and collection data from the numbers, interpret it inside tabulation form. In providing capital assistance it is really intended for the less fortunate by surveying every family that will be given capital assistance, tobe educated in providing training through bussiness management so that it can help customers increase income and be given capital so that they can grow to create businesses independently. Effect PNM MEKAAR on the income of the poor people in the Campalagian district is very influential, with the existence of the PNM MEKAAR Campalagian branch with the help of these capital communities who join a group that has managed its business well has been able to produce profits that can meet individual needs and family needs.

Keywords : PNM MEKAAR, Income of the poor
\end{abstract}

\section{PENDAHULUAN}

Kemiskinan adalah masalah multidimensi sebab berkaitan dengan kurang mampunya seseorang dari segi ekonomi, budaya, politik, sosial dan partisipasi dalam masyarakat. Bukan hanya sebagai masalah dalam kesejahteraan manusia, tetapi kemskinan juga mempunyai arti lebih luas sebab memiliki kaitan pula dengan 
ketidakmampuan dalam mencapai aspek di luar penghasilan misalnya kebutuhan minimum seperti pendidikan, air bersih, kesehatan dan lain-lain. ${ }^{1}$ Meski upaya untuk mengurangi kemiskinan sampai saat ini belum berjalan dengan baik, tetapi telah banyak cara dan penyelesaian yang dambil dalam mengurangi kemiskinan.

Oleh karena itu, dalam situasi kemiskinan yang dihadapi masyarakat Indonesia adalah masalah sosial yang sangat penting untuk dianalisis secara mendalam. Hal tersebut tidak disebabkan masalah kemiskinan sudah ada sejak lama tetapi permasalahan ini tetap berada lingkungan masyarakat bahkan kini gejalanya semakin bertambah sejalan dengan krisis multidimensional yang dihadapi oleh bangsa Indonesia. Meski upaya untuk mengurangi kemiskinan sampai saat ini belum berjalan dengan baik, tetapi telah banyak cara dan penyelesaian yang dambil dalam mengurangi kemiskinan. Menganalisis konsep kemiskinan merupakan strategi yang dapat menanggulangi masalah ekonomi dan upaya positif guna menghasilkan pendekatan yang dihadapi bangsa Indonesia.

Permodalan Nasional Madani (PNM) didirikan sebagai usaha yang ditempuh pemerintah yang menjadi lembaga pengelola keuagan dalam memajukan, memelihara maupun mengembangkan Usaha Mikro, Kecil dan Menengah (UMKM). PNM adalah lembaga yang memberikan pelatihan bagi pelaku usaha mikro serta merupakan solusi strategis pemerintah untuk mengembangkan akses permodalan yang tersebar di seluruh Indonesia. PNM diharapkan mampu menjadi lembaga keuangan yang dapat menciptakan nasabah yang mandiri dan tangguh dengan seratus persen kepemilikan sahamnya dipegang oleh pemerintah.

Permodalan Nasional Madani yaitu BUMN milik pemerintah yang memiliki peran dalam memberikan solusi pembiayaan kepada Usaha Mikro, Kecil, Menengah dan Koperasi (UMKMK) berdasarkan dengan kemampuan kelayakan usaha dalam prinsip ekonomi dasar. PNM Mekaar adalah program kerja yang memiliki tujuan dalam membimbing dan mensejahterakan masyarakat agar mencapai derajat kehidupan agar lebih baik. Pelayanan dalam pengelolaan pada PNM Mekaar lebih dikhususkan pada wanita pelaku usaha mikro dengan layanan berbasis kelompok atau tanggung renteng tanpa agunan dengan maksud mampu sebagai solusi adanya permasalahan terhadap akses pembiayaan untuk menjalankan usahanya, sehingga nasabah mengharapkan dapat mengembangkan maupun menjalankan usahanya dan pada akhirnya dapat mengubah perekonomian dalam rumah tangga.

Faktor pendukung keputusan dalam menentukan penerima bantuan program pemerintah adalah layanan aplikasi yang bisa digunakan oleh pemerintah Badan Pusat Statistik dengan menyeleksi rumah tangga miskin yang akan diberikan bantuan dana secara tunai dengan upaya meningkatkan pendidikan dan layanan kesehatan bagi masyarakat yang kurang mampu. Faktor tersebut dikarenakan sistem ini mempunyai berbagai macam penilaian dari rumah tangga miskin yang dirumuskan serta diperoleh dengan memperhatikan berbagai faktor yang dianggap perlu dan berguna.

Berangkat dari gambaran umum tentang latar belakang hadirnya program PNM MEKAAR yang tujuannya untuk menanggulangi kemiskinan dan meningkatkan kesejahteraan keluarga di kecamatan Campalagian secara berkelanjtan membuat calon

${ }^{1}$ Riadi Mendo Koestoer dkk, Dimensi Keuangan Kota Teori dan Kasus (Cet. 1; Jakarta: Universitas Indonesia, 2010) h. 1 
peneliti merasa tertarik untuk mengetahui bagaimana mekanisme kerja PNM MEKAAR dalam memberi bantuan permodalan serta bagaimana pengaruh PNM MEKAAR terhadap pendapatan masyarakat miskin di kecamatan Campalagian sebagai sumber pendapatan. Sehingga hal ini pula yang membuat calon peneliti mengambil judul Pengaruh Program PNM MEKAAR (Permodalan Nasional Madani Membina Ekonomi Keluarga Sejahtera) Terhadap Pendapatan Masyarakat Miskin Kecamatan Campalagian”.

\section{KAJIAN PUSTAKA}

\section{a. Program Permodalan Nasional Madani Membina Ekonomi Keluarga Sejahtera ( PNM MEKAAR)}

Pembiayaan program PNM MEKAAR adalah salah satu BUMN milik pemerintah yang memiliki tugas dalam memberikan penyelesaian pengelolaan terhadap Usaha Mikro, Kecil, Menengah dan Koperasi (UMKMK) berdasarkan dengan kapasitas yang pantas terhadap usaha maupun prinsip ekonomi dasar, sehingga PNM mempunyai program pengelolaan yang tidak sama dengan perbankan.

PNM Mekaar adalah program kerja yang memiliki tujuan dalam membimbing dan mensejahterakan masyarakat agar mencapai derajat kehidupan dengan lebih layak. Program pengelolaan pada PNM Mekaar lebih dikhususkan bagi wanita pelaku usaha mikro dengan sistem berbasis kelompok, sehingga mampu sebagai solusi jika terdapat kesulitan terhadap program pengelolaan untuk menjalankan usaha mikronya dan diharapkan agar nasabah dapat mengembangkan dan memajukan usahanya sehingga pada akhirnya dapat mengubah perekonomian keluarga. ${ }^{2}$

\section{b. Pendapatan}

Pendapatan adalah hasil usaha yang telah diperoleh perusahaan dari kegiatan yang dilakukan. Pendapatan adalah salah satu tolak ukur bagi manajemen untuk mengelola perusahaan yang pastinya ingin mengetahui jumlah maupun nilai penghasilan yang didapatkan dalam satu periode yang sesuai dengan prinsip-prinsip akuntansi yang berlaku. Pendapatan merupakan harta benda yang masuk dari penyerahan barang maupun jasa yang dijalankan dari suatu unit usaha dalam satu periode tertentu. ${ }^{3}$

Adapun macam-macam dari Pendapatan yaitu sebagai berikut:

1. Pendapatan dalam bentuk uang yaitu setiap pendapatan yang bersifat tetap serta didapat sebagai kontra prestasi atau balas jasa.

2. Pendapatan dalam bentuk barang yaitu setiap penghasilan yang sifatnya reguler dan diterima yang pastinya dalam bentuk barang.

3. Penerimaan dalam bentuk uang dan barang, seperti pinjaman uang hasil undian, warisan, penagihan, penjualan barang-barang yang dipakai, dan lain sebagainya. ${ }^{4}$

\section{c. Kemiskinan}

Kemiskinan merupakan kondisi yang terjadi akibat kurang mampunya seseorang dalam memenuhi kebutuhan dasar seperti sandang, pangan, papan kesehatan dan

\footnotetext{
${ }^{2}$ PT Permodalan Nasional Madani (Persero), Laporan Tahunan 2016 Annual Report

3 Baridwan, Zaki, Sistem Akuntansi, Penyusunan Prosedur dan Metode, Bagian Penerbitan Akademi Akuntansi (YKPN YogyakartaTahun 2000) h. 30

${ }^{4}$ Mulyanto Sumardi dan Hans Dieter Evers, Kemiskinan dan Kebutuhan Pokok (Jakarta: Rajawali, 2012), h. 65
} 
pendidikan. Masalah kualitas hidup yang rendah memiliki kaitan dalam tingkat pendidikan masyarakat yang rendah, perumahan yang kurang layak, pendapatan yang rendah, kesehatan dan pelayanan yang buruk sehingga berakibat pula terhadap rendahnya sumber daya manusia dan meningkatnya pengagguran. ${ }^{5}$

Miskin yaitu harta yang tidak mencukupi kebutuhan. Secara istilah arti yang terkandung adalah kemiskinan erat kaitannya dengan masalah konsumsi, karena kemiskinan hanya dilihat dari pandangan negatif (ketidakseimbangan) antar pekerja dan upah yang didapat. Sebagaimana yang dijelaskan dalam Undang-Undang Dasar 1945, pasal 34 yang menyatakan, bahwa: "fakir miskin dan anak-anak yang terlantar dipelihara oleh Negara". Dan selanjutnya diperkuat pengertiannya dengan PP No. 42 Pasal 1, yang berbunyi bahwa: "fakir miskin yaitu orang yang sama sekali tidak memiliki sumber mata pencaharian dan tidak memiliki kemampuan memenuhi kebutuhan pokok yang layak bagi kemanusiaan atau orang yang memiliki sumber mata pencahariaan akan tetapi tidak dapat memenuhi kebutuhan pokok yang layak bagi kemanusiaan". ${ }^{6}$

Sebagaimana firman Allah SWT dalam surah Ar-rum ayat 38:

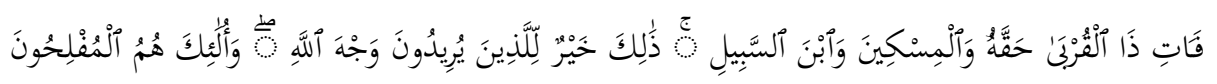

Artinya :

Maka berikanlah kepada kerabat yang terdekat akan haknya, demikian (pula) kepada fakir miskin dan orang-orang yang dalam perjalanan. Itulah yang lebih baik bagi orang-orang yang mencari keridhaan Allah; dan mereka Itulah orang-orang beruntung (QS. Ar$\mathrm{rum} / 30: 38)$.

Michael P. Tadaro dan Stephen C. Smith $(2009,2011)$, mengemukakan bahwa kemiskinan terbagi menjadi lima kategori yaitu: ${ }^{7}$

1. Kemiskinan Absolut

Kemiskinan absolut adalah kemiskinan yang tidak didasari dan tidak merujuk terhadap tingkat kemiskinan yang rendah. Kemiskinan absolut merupakan tingkat kemiskinan yang rendah, diamana kebutuhan minimum untuk bertahan hidup tidak mampu untuk dipenuhi. ${ }^{8}$

\section{Kemiskinan Relatif}

Kemiskinan relatif yaitu adanya penimpangan pendapatan dalam masyarakat antara yang kaya dengan yang miskin atau dikenal dengan istilah ketimpangan distribusi pendapatan.

3. Kemiskinan Struktural

\footnotetext{
${ }^{5}$ Sadono Sukirno, Ekonomi Pembangunan. Proses, masalah dan Dasar Kebijakan (Edisi Kedua. Rencana;Jakarta 2006) h. 133.

${ }^{6}$ Ben Akrom Kasyaf, Dahsyatnya Menyantuni Fakir Miskin (Cet. 1;Jakarta Timur: Al Maghfiroh, 2012) h. 14

${ }^{7}$ Michael P. Tadaro dan Stephen C Smith, Pembangunan Ekonomi di Dunia Ketiga (Edisi Keenam Jilid 1. Erlangga; Jakarta, 2009,2011) h. 178

8 Tulus Tambunan, Perekonomian Indonesia.Beberapa Masalah Penting ( Ghalia Indonesia; Jakarta, 2003) h. 84
} 
Michael P. Tadaro dan Stephen C. Smith (2009,2011), menyatakan bahwa kemiskinan struktural merujuk kepada setiap orang maupun masyarakat yang diakibatkan dari segi budaya yang tidak ingin berusaha dalam meningkatkan derajat kehidupan walaupun terdapat usaha dari pihak lain yang mendukungnya dan dapat pula diukur dari kurangnya perlindungan dari pemerintah maupun hukum sebagai birokrasi serta peraturan resmi yang mencegah seseorang memanfaatkan kesempatan yang ada. ${ }^{9}$

\section{Kemiskinan Kronis}

Kemiskinan kronis disebabkan dari berbagai faktor, seperti kondisi sosial dan budaya yang mendorong sikap maupun kebiasaan hidup masyarakat yang tidak produktif. Keterbatasan sumber daya dan keterisolasian (daerah-daerah kritis terhadap sumber daya alam dan daerah terpencil). Terbatasnya lapangan kerja, rendahnya tingkat pendidikan dan perawatan kesehatan, serta ketidakmampuan banyak orang untuk mengikuti ekonomi pasar.

Sebagaimana Allah SWT berfirman dalam surah Adz-Dzariyat ayat: 19

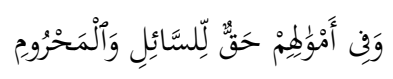

Artinya:

Dan pada harta-harta mereka ada hak untuk orang miskin yang meminta dan orang miskin yang tidak mendapat bagian (QS. Adz-Dzariyat/51: 19)

\section{Kemiskinan Sementara}

Kemiskinan sementara diakibatkan adanya perubahan siklus ekonomi dari kondisi normal menjadi krisis ekonomi, perubahan yang bersifat musiman, bencana alam atau dampak dari suatu yang menyebabkan tingkat kesejahteraan suatu masyarakat. ${ }^{10}$

\section{METODE PENELITIAN}

Jenis penelitian yang digunakan yaitu penelitian deskriptif .Tujuan dari penelitian deskriptif yaitu untuk menggambarkan/ memecahkan masalah secara akurat, faktual, dan sistematis mengenai fakta dan sifat populasi atau daerah tertentu. ${ }^{11}$ Penelitian deskriptif adalah penelitian yang paling sederhana jika dibandingkan dengan penelitian yang lain sebab dalam penelitian ini peneliti tidak melakukan apa-apa terhadap wilayah maupun objek yang akan diteliti, itu berarti bahwa peneliti tidak menambah, mengadakan atau mengubah manipulasi terhadap objek atau wilayah penelitian. Dalam penelitian ini peneliti menggunakan pendekatan kuantitatif untuk mengumpulkan data sebagai data pendukung terhadap penelitian dalam hal penggambaran pengaruh program PNM MEKAAR terhadap pendapatan masyarakat Kecamatan Campalagian.

Penelitian kuantitatif yaitu jenis penelitian yang pada dasarnya menggunakan pendekatan deduktif-induktif. Pendekatan ini berangkat dari suatu gagasan para ahli, kerangka teori maupun pemahaman peneliti berdasarkan pengalamannya, selanjutnya

\footnotetext{
${ }^{9}$ Michael P. Tadaro dan Stephen C Smith, Pembangunan Ekonomi di Dunia Ketiga, h. 182

${ }^{10}$ Michael P. Tadaro, Pembangunan Ekonomi di Dunia Ketiga, h. 150

11 Usman Rianse dan Abdi, Metodologi Penelitian Sosial dan Ekonomi Teori dan Aplikasi (Bandung: Alfabeta, 2012), h. 30
} 
dikembangkan menjadi permasalahan-permasalahan serta pemecahannya yang diajukan untuk mendapat penilaian atau pembenaran (verifikasi) dalam bentuk dukungan data empiris di lapangan. ${ }^{12}$

Populasi digunakan untuk merumuskan seluruh komponen/anggota dari suatu wilayah yang menjadi bahan penelitian atau merupakan keseluruhan dari objek penelitian. Adapun populasi dari penelitian ini yaitu nasabah PNM MEKAAR Kecamatan Campalagian. Berikut adalah tabel jumlah nasabah PNM MEKAAR Kecamatan Campalagian.

Sampel adalah bagian dari jumlah dan karakteristik yang dimiliki oleh populasi yang akan diteliti. Penarikan sampel yang digunakan dalam penelitian ini yaitu menggunakan teknik acak sederhana yang merupakan suatu teknik yang memberikan kesempatan yang sama terhadap setiap anggota populasi untuk dipilih sebagai sampel, teknik acak sederhana juga dipakai sebab populasi penelitian bersifat homogen dan tidak banyak jumlahnya. Pengambilan sampel menggunakan rumus dari Slovin dengan tingkat kesalahan $10 \% .^{13}$

$$
\begin{aligned}
\mathrm{n} & =\frac{N}{1+N(e)^{2}} \\
\mathrm{n} & =\frac{820}{1+820(0,1)^{2}} \\
\mathrm{n} & =\frac{820}{1+820(0,01)}=89,13=90
\end{aligned}
$$

Keterangan

$\mathrm{n}$ : Besaran sampel

$\mathrm{N}$ : Besaran populasi

e : Nilai kritis (batas ketelitian) yang diinginkan (persen kelonggaran ketidaktelitian karena kesalahan penarikan sampel) yaitu sebesar $10 \%$ dengan tingkat kepercayaan $90 \%$

Berdasarkan dari hasil perhitungan diatas, maka diperoleh ukuran sampel sebesar 90 orang yang mengambil kredit permodalan di PNM MEKAAR Kecamatan Campalagian.

Variabel yang digunakan ada 2 yaitu Variabel bebas dalam penelitian ini yaitu Program PNM MEKAAR (X) dan Variabel terikat di dalam penelitian ini yaitu Pendapatan Masyarakat Miskin (Y).

Dalam penelitian ini sumber data yang digunakan yaitu subyek/obyek dari mana data diperoleh. Sumber data dalam penelitian ini dikelompokkan menjadi dua macam yaitu data primer dan data sekunder

Berikut adalah empat teknik pengumpulan data yang digunakan yaitu:

Angket atau kuesioner merupakan suatu daftar yang berisi berbagai pertanyaan mengenai suatu masalah atau bidang yang akan diteliti. ${ }^{14}$

12 Tim Labolatorium Jurusan, Pedoman Penyusunan Skripsi STAIN Tulungagung (Tulungagung:STAIN Tulungagung, 2012), h.19

13 Bambang Prasetyo, Metode penelitian Kuantitatif : Teori dan Aplikasi, Raja Grafindo Persada: Jakarta, 2006 h. 137 2010), h. 76

${ }_{76}^{14}$ Cholid Narbukon, dan Abu Achmadi, Metodologi Penelitian (Cet-11, PT. Bumi Aksara, Jakarta, 
Observasi (Pengamatan) yaitu teknik pengumpulan data yang tidak hanya mengukur sikap dari responden dari angket dan wawancara, tetapi juga dapat digunakan untuk merekam berbagai peristiwa yang terjadi (situasi, kondisi).

Wawancara digunakan sebagai teknik pengumpulan data jika peneliti ingin melakukan studi pendahuluan dalam menemukan permasalahan yang harus diteliti, atau peneliti ingin mengetahui hal-hal dari responden yang lebih mendalam dan jumlah respondennya sedikit/kecil. ${ }^{15}$

Dokumentasi merupakan pengumpulan data yang dilakukan oleh peneliti melalui dokumen, informasi ataupun hasil wawancara dari nasabah yang meminjam modal di PNM MEKAAR untuk membuka usaha dan dijadikan sebagai narasumber wawancara yang berkaitan dengan penelitian ini.

Instrumen penelitian yang digunakan bergantung pada metode pengumpulan data yang digunakan. Instrumen yang digunakan dalam penelitian ini berupa angket/kuesioner.

Salah satu cara untuk memenuhi syarat penelitian ilmiah yaitu dipenuhi dengan alat ukur dalam memperoleh suatu pengukuran yang cermat yaitu validitas dan reliabilitas. . Validitas adalah suatu ukuran yang menunjukkan tingkat kesahihan suatu tes. Reliabilitas adalah tingkat konsistensi suatu tes, yaitu seberapa jauh suatu tes dapat dipercaya untuk menghasilkan skor yang konsisten, relatif tidak berubah walaupun digunakan berkali-kali oleh peneliti yang sama atau oleh peneliti lain tetap memberikan hasil yang relatif sama. ${ }^{16}$

Bambang Prasetyo (2006) mengemukakan bahwa pengolahan data dilakukan dengan: ${ }^{17}$

Pengkodean data yaitu suatu proses penyusunan secara sistematis data mentah dari kuesioner dengan ketentuan yang ada.

Editing dalam tahapan ini, data yang telah terkumpul melalui daftar pertanyaan maupun pernyataan (kuesioner) harus dibaca kembali atau dengan kata lain, mengoreksi atau meneliti kembali jawaban responden.

Tabulating merupakan data yang dimasukkan kedalam tabel tertentu kemudian menghitungnya.

Tahap selanjutnya yaitu data yang diperoleh berfungsi sebagai dasar penarikan kesimpulan dan difungsikan mampu menjawab masalah yang dimaksud dalam penelitian ini.

Teknik Analisis Data merupakan proses mencari dan menyusun secara sistematis data yang diperoleh dari hasil wawancara, catatan lapangan dan hasil dokumentasi dengan cara mengorganisasikan data ke dalam kategori, menyusun ke dalam pola, melakukan penggabungan teori, menjabarkan ke dalam unit-unit, memilih mana yang

${ }^{15}$ Prof.Dr.Sugiyono, Metode Penelitian Kuantitatif Kualitatif dan R\&D (Alfabeta: Bandung, 2011),

h. 137

${ }^{16}$ Hamzah B, Pengembangan Isntrumen Untuk Penelitian (Jakarta: Delima Press, 2010), h. 141

${ }^{17}$ Bambang Prasetyo, Metode penelitian Kuantitatif : Teori dan Aplikasi, h. 171 
penting dan yang akan dipelajari dan membuat kesimpulan sehingga mudah difahami oleh diri sendiri dan orang lain. ${ }^{18}$

Perhitungan teknik anlisis data yang digunakan adalah:

$$
\mathrm{P}=\frac{f}{n} \times 100 \%
$$

Keterangan:

$\mathrm{P}=$ Presentase skor

$\mathrm{f}=$ Jumlah jawaban yang diperoleh

$\mathrm{n}=$ Jumlah responden.$^{19}$

\section{HASIL DAN PEMBAHASAN}

Berdasarkan hasil observasi yang telah dilakukan peneliti dilapangan diketahui bahwa program PNM MEKAAR yang merupakan program pemerintah di ajukan kepada ibu rumah tangga produktif yang ingin menjalankan usaha baik yang ingin memulai maupun melanjutkan usaha dengan mengajukan kredit pinjaman ke PNM MEKAAR dan berdasarkan dari hasil angket (kuesioner) yang telah peneliti sebarkan kepada nasabah dengan beberapa pihak tertentu, maka penulis dapat melakukan pengolahan data sebagai berikut:

A. Mekanisme kerja PNM MEKAAR dalam menjalankan program bantuan permodalan.

Tabel 1 Distribusi Frekuensi responden tentang Dari mana anda mendapatkan informasi mengenai Permodalan Nasional Madani Membina Ekonomi Keluarga Sejahtera (PNM Mekaar)

\begin{tabular}{|c|l|c|c|}
\hline No & \multicolumn{1}{|c|}{ Pernyataan } & Frekuensi & Presentase \\
\hline 1 & $\begin{array}{l}\text { Sosialisasi dari pemerintah } \\
\text { (PNM Mekaar) }\end{array}$ & 48 & $53 \%$ \\
\hline 2 & Teman atau tetangga & 32 & $36 \%$ \\
\hline 3 & Mencari informasi sendiri & 10 & $11 \%$ \\
\hline 4 & Lainnya & - & - \\
\hline \multicolumn{2}{|l}{ Jumlah } & 90 & $100 \%$ \\
\hline
\end{tabular}

Keterangan: Diolah dari angket No. 1

Dari hasil frekuensi Tabel di atas menunjukkan bahwa dari 90 responden terdapat 48 nasabah atau 53\% yang berpendapat bahwa dalam mendapatkan informasi mengenai PNM MEKAAR Cabang Campalagian ini melalui sosialisasi dari pemerintah PNM MEKAAR Cabang Campalagian, 32 responden atau 36\% yang mengatakan dari teman atau tetangga dan 10 responden atau $11 \%$ mencari informasi sendiri.

\footnotetext{
${ }^{18}$ Sugiono, Metode Penelitian Pendidikan: Pendekatan Kuantitatif, Kualitatif, dan R\&D. (Bandung Alfabeta, 2009), h. 335

${ }^{19}$ Kountur, Ronny, Metode Penelitian Untuk Penulisan Skripsi dan Tesis, Jakarta 2005: PPM, h. 16
} 
Tabel 2 Distribusi Frekuensi responden tentang Apakah lokasi PNM Mekaar Cabang Campalagian berada di tempat yang stategis dan mudah dijangkau

\begin{tabular}{|c|l|c|c|}
\hline No & \multicolumn{1}{|c|}{ Pernyataan } & Frekuensi & Presentase \\
\hline 1 & Sangat strategis & 12 & $13 \%$ \\
\hline 2 & Strategis & 45 & $50 \%$ \\
\hline 3 & Cukup strategis & 23 & $26 \%$ \\
\hline 4 & Tidak strategis & 10 & $11 \%$ \\
\hline \multicolumn{2}{|c|}{ Jumlah } & 90 & $100 \%$ \\
\hline
\end{tabular}

Keterangan: Diolah dari angket No.2

Dari hasil frekuensi Tabel diatas menunjukkan bahwa dari 90 responden terdapat 45 nasabah atau 50\% yang berpendapat bahwa lokasi PNM MEKAAR Cabang Campalagian yang berada dusun puppole desa Bonde Kecamatan Campalagian sudah strategis dalam memenuhi kebutuhan nasabah, 23 responden atau $26 \%$ nasabah yang mengatakan lokasi PNM MEKAAR cukup strategis, kemudian 12 responden atau $13 \%$ nasabah yang mengatakan lokasi PNM MEKAR sudah sangat strategis, sedangkan 10 responden atau $11 \%$ nasabah berpendapat bahwa lokasi PNM MEKAAR tidak strategis.

Tabel 3 Frekuensi responden tentang Berapa jumlah kredit yang diperoleh

\begin{tabular}{|c|l|c|c|}
\hline No & \multicolumn{1}{|c|}{ Pernyataan } & Frekuensi & Presentase \\
\hline 1 & RP.500.000-RP.1.000.000 & 8 & $9 \%$ \\
\hline 2 & RP.1.000.000-RP.2.000.000 & 42 & $47 \%$ \\
\hline 3 & RP.2.000.000-RP.3.000.000 & 30 & $33 \%$ \\
\hline 4 & Lainnya & 10 & $11 \%$ \\
\hline \multicolumn{2}{|l|}{ Jumlah } & 90 & $100 \%$ \\
\hline
\end{tabular}

Keterangan: Diolah dari angket No.3

Dari hasil frekuensi Tabel di atas didapatkan presentase $9 \%$ untuk peminjam nominal RP.500.000 sampai RP.1.000.000, 47\% untuk peminjam nominal RP.1.000.000 sampai RP.2.000.000, 33\% untuk peminjam nominal RP.2.000.000 sampai RP.3.000.000, dan didapatkan presentase $11 \%$ untuk peminjam lainnya atau di atas RP.3000.000.

Tabel 4 Distribusi Frekuensi respoden tentang Bagaimana menurut anda persyaratan prosedur pemanfaatan kredit bantuan permodalan

\begin{tabular}{|c|l|c|c|}
\hline No & \multicolumn{1}{|c|}{ Pernyataan } & Frekuensi & Presentase \\
\hline 1 & Sangat baik & 30 & $33 \%$ \\
\hline 2 & Baik & 42 & $47 \%$ \\
\hline 3 & Cukup baik & 18 & $20 \%$ \\
\hline 4 & Kurang baik & - & - \\
\hline \multicolumn{2}{|l}{ Jumlah } & 90 & $100 \%$ \\
\hline
\end{tabular}

Keterangan: Diolah dari angket No.4

Hasil presentase dari persyaratan prosedur pemanfaatan dana kredit menunjukkan bahwa $47 \%$ nasabah berpendapat dengan baik dalam pemenuhan prosedur persyaratan bantuan permodalan. 
Tabel 5 Distribusi Frekuensi responden tentang Bagaimana menurut anda mekanisme kerja PNM Mekaar dalam menjalankan program bantuan permodalan

\begin{tabular}{|c|l|c|c|}
\hline No & Pernyataan & Frekuensi & Presentase \\
\hline 1 & Sangat baik & 25 & $28 \%$ \\
\hline 2 & Baik & 45 & $50 \%$ \\
\hline 3 & Cukup baik & 20 & $22 \%$ \\
\hline 4 & Kurang baik & - & - \\
\hline \multicolumn{2}{|l|}{ Jumlah } & 90 & $100 \%$ \\
\hline
\end{tabular}

Keterangan: Diolah dari angket No.5

Hasil presentase Tabel di atas menunjukkan bahwa dari 90 responden terdapat 45 nasabah atau 50\% mengatakan bahwa mekanisme kerja PNM MEKAAR dalam menjalankan bantuan permodalan dengan baik, 25 responden atau 28\% nasabah mengatakan sangat baik dan 20 responden atau $22 \%$ nasabah mengatakan cukup baik.

Tabel 6 Distribusi Frekuensi responden tentang Bagaimana sistem premi yang dibayarkan tiap minggunya

\begin{tabular}{|c|l|c|c|}
\hline No & \multicolumn{1}{|c|}{ Pernyataan } & Frekuensi & Presentase \\
\hline 1 & Sangat baik & 24 & $27 \%$ \\
\hline 2 & Baik & 56 & $62 \%$ \\
\hline 3 & Cukup baik & 10 & $11 \%$ \\
\hline 4 & Kurang baik & - & - \\
\hline & Jumlah & 90 & $100 \%$ \\
\hline
\end{tabular}

Keterangan: Diolah dari angket No.6

Dari hasil frekuensi Tabel di atas menunjukkan bahwa 56 responden atau $62 \%$ nasabah mengatakan sistem premi yang dibayarkan tiap minggunya sudah baik, nasabah merasa tidak begitu sulit dengan jumlah premi yang dibayarkan tiap minggunya, 24 responden atau $27 \%$ nasabah mengatakan sangat baik, dan 10 responden atau $11 \%$ nasabah mengatakan cukup baik. Berdasarkan wawancara peneliti dengan salah satu nasabah PNM MEKAAR.

Tabel 7 Distribusi Frekuensi responden tentang Adakah pendampingan usaha yang dilakukan oleh PNM Mekaar? Jika ada Bagaimana sistem pendampingan usaha yang dilakukan

\begin{tabular}{|c|l|c|c|}
\hline No & Pernyataan & Frekuensi & Presentase \\
\hline 1 & Sangat baik & 28 & $31 \%$ \\
\hline 2 & Baik & 42 & $47 \%$ \\
\hline 3 & Cukup baik & 20 & $22 \%$ \\
\hline 4 & Kurang baik & - & - \\
\hline \multicolumn{2}{|c|}{ Jumlah } & 90 & $100 \%$ \\
\hline
\end{tabular}

Keterangan: Diolah dari angket No.7

Dari frekuensi Tabel di atas menunjukkan bahwa dari 90 rersponden terdapat 42 responden atau $47 \%$ nasabah mengatakan pendampingan usaha yang dilakukan oleh PNM MEKAAR tersebut baik, 28 responden atau 31\% nasabah mengatakan sangat baik, dan 20 responden atau $22 \%$ nasabah mengatakan cukup baik. 
Tabel 8 Distribusi Frekuensi responden tentang Bagaimana sistem pelayanan yang diberikan saat pengajuan kredit

\begin{tabular}{|c|l|c|c|}
\hline No & Pernyataan & Frekuensi & Presentase \\
\hline 1 & Sangat baik & 28 & $31 \%$ \\
\hline 2 & Baik & 42 & $47 \%$ \\
\hline 3 & Cukup baik & 20 & $22 \%$ \\
\hline 4 & Kurang baik & - & - \\
\hline \multicolumn{2}{|l|}{ Jumlah } & 90 & $100 \%$ \\
\hline
\end{tabular}

Keterangan: Diolah dari angket No.8

Dari hasil presentase Tabel diatas menunjukkan bahwa dari 90 responden terdapat 42 nasabah atau $47 \%$ mengatakan bahwa pelayanan yang diberikan petugas PNM MEKAAR pada saat pengajuan kredit baik, 28 responden atau $31 \%$ nasabah mengatakan sangat baik dan 20 responden atau $22 \%$ nasabah mengatakan sistem pelayanan yang diberikan petugas PNM MEKAAR Cabang Campalagian cukup baik.

B. Pengaruh program PNM MEKAAR terhadap pendapatan masyarakat miskin Kecamatan Campalagian.

Tabel 9 Distribusi Frekuensi responden tentang Berapa pendapatan anda perbulan sebelum memanfaatkan kredit bantuan permodalan

\begin{tabular}{|c|l|c|c|}
\hline No & \multicolumn{1}{|c|}{ Pernyataan } & Frekuensi & Presentase \\
\hline 1 & RP.100.000-RP.250.000 & 58 & $64 \%$ \\
\hline 2 & RP.250.000-RP.500.000 & 15 & $17 \%$ \\
\hline 3 & RP. $\geq 500.000$ & 10 & $11 \%$ \\
\hline 4 & Tidak ada & 7 & $8 \%$ \\
\hline \multicolumn{2}{|l|}{ Jumlah } & 90 & $100 \%$ \\
\hline
\end{tabular}

Keterangan: Diolah dari angket No.1

Dari hasil frekuensi Tabel di atas menunjukkan bahwa 58 responden atau $64 \%$ nasabah memiliki pendapatan perbulan sebelum memanfaatkan kredit bantuan permodalan dengan nominal RP.100.000-RP.250.000, 15 responden atau 17\% nasabah memiliki pendapatan dengan nominal RP.250.000-RP.500.000, kemudian 10 nasabah atau $11 \%$ memiliki pendapatan RP. $\geq 500.000$, dan 7 responden atau $8 \%$ nasabah tidak memiliki pendapatan. Pendapatan tersebut tidak menentu kadang berubah-ubah sebagaimana berdasarkan wawancara peneliti dengan salah satu nasabah PNM MEKAAR.

Tabel 10 Distribusi Frekuensi responden tentang Berapa pendapatan anda perbulan sesudah memanfaatkan kredit bantuan permodalan

\begin{tabular}{|c|l|c|c|}
\hline No & \multicolumn{1}{|c|}{ Pernyataan } & Frekuensi & Presentase \\
\hline 1 & RP.100.000-RP.250.000 & - & - \\
\hline 2 & RP.250.000-RP.500.000 & 43 & $48 \%$ \\
\hline 3 & RP.500.000-RP.1000.000 & 22 & $24 \%$ \\
\hline
\end{tabular}




\begin{tabular}{|c|l|c|c|}
\hline 4 & RP. $\geq 1000.000$ & 25 & $28 \%$ \\
\hline \multicolumn{2}{|c|}{ Jumlah } & 90 & $100 \%$ \\
\hline
\end{tabular}

Keterangan: Diolah dari angket No.2

Dari hasil frekuensi tabel di atas menunjukkan bahwa 43 responden atau $48 \%$ nasabah memiliki pendapatan sesudah memanfaatkan bantuan permodalan dengan nominal RP.250.000-RP.500.000, 22 responden atau 24\% nasabah memiliki pendapatan dengan nominal RP.500.000-RP.1000.000, dan 25 responden atau $28 \%$ nasabah memiliki pendapatan RP. $\geq 1000.000$.

\section{KESIMPULAN}

Mekanisme kerja PNM MEKAAR Dalam Memberikan Bantuan Permodalan benar-benar ditujukan untuk masyarakat yang kurang mampu dengan mensurvei setiap keluarga yang akan diberikan bantuan modal, untuk dididik dalam memberikan pelatihan melalui pengelolaan usaha sehingga dapat membantu nasabah dalam meningkatkan pendapatan dan diberikan modal agar mereka dapat tumbuh menciptakan usaha secara mandiri.

Pengaruh PNM MEKAAR Terhadap Pendapatan Masyarakat Miskin Kecamatan Campalagian sangat berpengaruh. Dengan adanya program PNM MEKAAR Cabang Campalagian dengan bantuan permodalan tersebut masyarakat yang bergabung dalam suatu kelompok yang telah mengelola usahanya dengan baik telah dapat menghasilkan keuntungan yang sudah dapat memenuhi kebutuhan individu maupun kebutuhan keluarga. Dapat dibandingkan setelah bergabung dan memanfaatkan bantuan permodalan hasil pendapatan sebelum dan sesudah memanfaatkan bantuan permodalan tersebut sangat jauh berbeda. Hal ini diukur dari banyaknya nasabah yang sudah tidak bergantung lagi memanfaatkan kredit bantuan permodalan karena sudah mampu mengelola sendiri dan mendapatkan penghasilan dari usaha yang dijalankan.

\section{DAFTAR PUSTAKA}

Ali Lukman dkk. Kamus Besar Bahasa Indonesia (Jakarta: Balai Pustaka, Edisi II, cetakan VII, 2008)

Arifin Imamul. Membuka Cakrawala Ekonomi Untuk Kelas XI SMA, Tahun 2009

Arikunto Suharsimi. Prosedur Penelitian, (Jakarta: Rineka Cipta, 2010)

Baridwan. Zaki. Sistem Akuntansi, Penyusunan Prosedur dan Metode, Bagian Penerbitan Akademi Akuntansi (YKPN YogyakartaTahun 2000)

Bintari dan Suprihatin. Ekonomi dan Koperasi (Bandung: Ganecea Exact, 2008),

Departemen Pendidikan dan Kebudayaan. Kamus Besar Bahasa Indonesia (Jakarta: Balai Pustaka,2010)

Djali dan Muljono Pudji. Pengukuran dalam Bidang Pendidikan (Jakarta: PT. Gramedia Widiasarana, 2008)

Hamzah B. Pengembangan Isntrumen Untuk Penelitian (Jakarta: Delima Press, 2010) 
Kasyaf Ben Akrom. Dahsyatnya Menyantuni Fakir Miskin (Cet. 1;Jakarta Timur: Al Maghfiroh, 2012)

Kieso, E Donald E, J Jerry, Weigandt, D Terry, Warfield, Akuntansi Intermediate (Edisi 12; Jakarta. Erlangga,2008)

Koestoer Riadi Mendo dkk, Dimensi Keuangan Kota Teori dan Kasus (Cet. 1; Jakarta: Universitas Indonesia, 2010)

Kountur, Ronny. Metode Penelitian Untuk Penulisan Skripsi dan Tesis, Jakarta 2005: PPM

Lestari Nanda. Pengaruh PT. Permodalan Nasional Madani Medan Terhadap Usaha Mikro Kecil (UMK) di Kota Medan, Tahun 2018

Nur Rachman Winardi. Pengaruh Penyertaan Saham dan Pembiayaan Bagi Hasil Perusahaan PNM Modal Ventura Terhadap Profit PNM Modal Ventura, Samarinda Tahun 2018

Narbuko Cholid dan Achmadi Abu. Metodologi Penelitian ( Cet-11, Jakarta: PT. Bumi Aksara 2009)

Pusat Bahasa Departemen Pendidikan Nasional. Kamus Umum Bahasa Indonesia, (Jakarta: Balai Pustaka, 2007)

Pusat Bahasa Departemen Pendidikan Nasional. Kamus Besar Bahasa Indonesia (Edisi III, Jakarta;Balai Pustaka, 2017) hal. 897

Tadaro P Michael . Pembangunan Ekonomi di Dunia Ketiga (Edisi Keenam Jilid 1. Erlangga; Jakarta, 2009,2011)

Puspowarsito. Metode Penelitian Organisasi (Bandung, Humaniora, 2008)

Prasetyo Bambang. Metode penelitian Kuantitatif : Teori dan Aplikasi, Raja Grafindo Persada: Jakarta, 2006

Rianse Usman dan Abdi. Metodologi Penelitian Sosial dan Ekonomi Teori dan Aplikasi (Bandung: Alfabeta, 2012)

Stice, D James, K Earl. Stice, K.Fred Skousen. Akuntansi Keuangan Menengah (Edisi 16, Buku 2. Edisi Bahasa Indonesia. Terjemah Oleh Ali Akbar. PT. Salemba Empat: Jakarta)

Sumardi Mulyanto dan Hans Dieter Evers. Kemiskinan dan Kebutuhan Pokok (Jakarta: Rajawali, 2012)

Sukirno Sadono. Ekonomi Pembangunan. Proses, masalah dan Dasar Kebijakan (Edisi Kedua. Rencana;Jakarta 2006)

Sarwat Ahmad. fikih Sehari-hari (Cet. 2; Jakarta: PT Gramedia Pustaka Utama, 2017)

Suryana. Ekonomi Pembangunan Problematika dan Pendekatan (Salemba Empat; Jakarta, 2000)

Sugiyono. Metode Penelitian Kuantitatif Kualitatif dan $R \& D$ (Alfabeta CV: Bandung, 2014)

Tambunan Tulus. Perekonomian Indonesia.Beberapa Masalah Penting ( Ghalia Indonesia; Jakarta, 2003)

Tim Labolatorium Jurusan. Pedoman Penyusunan Skripsi STAIN Tulungagung (Tulungagung:STAIN Tulungagung, 2012) 